\title{
Liability of Judicial Officers Under Section 1983
}

Congress phrased Section 1983 of the Civil Rights Act of $1871^{1}$ as broadly as a remedial statute can be written; it declares that "every person" who, acting under color of state law, deprives anyone of a constitutional right, is liable in damages to the injured party. Yet this apparently unambiguous statement of complete coverage has been held to exclude liability of judicial officers. ${ }^{2}$ This Note contends that the congressional intent of Section 1983 and the policies underlying this exemption do not support a grant of judicial immunity, but rather argue for judicial liability under an actual malice standard. ${ }^{3}$

1. This was the first section of the Civil Rights Act of 1871, 17 Stat. 18:

Every person who, under color of any statute, ordinance, regulation, custom, or usage, of any State or Territory, subjects or causes to be subjected, any citizen of the United States or other person within the jurisdiction thereof to the deprivation of any rights, privileges, or immunities secured by the Constitution and laws, slall be liable to the party injured in an action at law, suit in equity, or other proper pro. ceeding for redress.

2. The term "judicial officers" is at least inclusive of: judges, Carpenter v. Dethmers, 253 F.2d 131 (6th Cir. 1958), justices of the peace, Tate v. Arnold, 223 F.2d 782 (8th Cir. 1955), prosecuting attorneys, Sires v. Cole, 320 F.2d 877 (9th Cir. 1963), and other offlecrs of the court, Rhodes v. Meyer, 334 F.2d 709 (8th Cir.), cert. denied, 379 U.S. 915 (1961). In addition, common law immunity (and therefore $\$ 1983$ immunity) applies to "quasi judicial" officers ("those officers who are called upon to exercise judgment and discretion, but not in courts . . "). F. MEchem, A TREATISE ON THE LAW OF Public OFFices AND OFFICERS § 618 (1890). Silver v. Dickson, 403 F.2d 642 (9th Cir. 1968) (State Parole Board Member); Erlich v. Glasner, 274 F. Supp. 11 (C.D. Cal. 1967) (Kosher Food Law Rcpresentative); Jones v. Kennedy, 121 F.2d 40 (D.C. Cir. 1941) (SEC Member); Lang v. Wood, 92 F.2d (D.C. Cir. 1937) (Prison Warden); Phelps v. Dawson, 97 F.2d 339 (3rd Cir. 1937) (Fire Marshall). The term "judicial officers" will be used hereafter to refer to both judiclal and quasi judicial officers. The liability of judges is of primary concern since their immunity has the deepest historical roots and since judges represent the cpitome of the discretionary function for which the immunity is given. If judges are to be held liable to $\S 1983$ actions, the liability of other judicial officers should follow a fortiori. However, some other judicial officers may have considerably more discretion than judges, at least to the extent that judges may consider themselves bound by a set of precedents and a hierarchy of courts.

3. "Actual malice" is used here analogously to its use in New York Times v. Sullivan, 376 U.S. 254 (1964), where the term was defined in relation to a libel action as publication "with knowledge that it was false or with reckless disregard of whether it was false or not." Id. at 280. Applied to a judicial officer, this would mean that an action would be malicious if it was done with actual knowledge that it was incorrect or with reckless disregard of whether it was incorrect or not. An alternative would be to use the "will. fulness" standard specified in 18 U.S.C. $\$ 242$, an analogous provision in the criminal code. The word "willful" means "not merely a 'conscious purpose to do wrong' on the part of an officer ... . but that there must be a specific intent to deprive him of a federal right," Pullen v. U.S., 164 F.2d 756, 759 (5th Cir. 1947). However, "malice" is a term much more familiar to tort law, and it would seem anomalous to use specific intent, a doctrine so closely associated with criminal law, in a tort context. Further, there scems to be no good reason why a tort plaintiff should be required to show conduct amounting to a criminal act in order to be indemnified. "Actual malice," despite the definition in Sullivan, is by no means clearly defined. In practice, it may be simply an area on the standards-of-liability continuum more stringent than simple negligence and less de. manding than specific intent.

Some commentators have suggested that the "reckless disregard" standard of Sullivan is so hard to meet that it is the equivalent of actual culpable knowledge. Notc, The Actual Malice Test and "Public Figures," 46 N.C.L. REv. 392, 395 (1968); Note, New Yori" 
In Pierson v. Ray ${ }^{4}$ the Supreme Court finally held the doctrine of absolute judicial immunity applicable to actions under Section 1983.5 Pierson arose out of the 1961 arrest and conviction for breach of the peace $^{6}$ of nine clergymen engaged in a "freedom ride." After the county court reversed their conviction, the clergymen brought suit under Section 1983 against the police magistrate who had convicted them.

Chief Justice Warren, speaking for the Court, determined that the suit could not be maintained. The court found "no difficulty" in following the century-old rule of Bradley $v$. Fisher, ${ }^{7}$ holding judges absolutely immune from common law tort actions for acts committed in their judicial capacity. The Court's argument gained strength from Tenney $v$. Brandhove, ${ }^{8}$ which held state legislators acting in their official capacity immune from Section 1983 suits. "The immunity of judges for acts within the judicial role is equally well-established," the Court declared, "and we presume that Congress would have specifically so provided had it wished to abolish the doctrine."

The doctrine of judicial immunity is indeed old, going back at least to $1608,{ }^{10}$ and is entirely judge-made. ${ }^{11}$ The common-law rule is

Times Co. v. Sullivan-The Scope of a Privilege, 51 VA. L. Rxv. 106, 117 (1965). However. as Sullivan itself illustrates, the problem is often in finding a duty to investigate on the part of the defendant. In dealing with judicial offcers, the duty to investigate is alviajs present. Therefore, "reckless disregard" would probably acquire more meaning in actions against judicial officers than in actions against publishers.

4. 386 U.S. 547 (1967).

5. The Court had had many previous opportunities to rule on the issue, but had denied certiorari. All of the cases in which certiorari was denied had found the judicial officers immune from $\$ 1983$ liability. Arnold v. Bostick, 339 F2d 879 (9th Cir. 1964), cert. denied 382 U.S. 858 (1965); Rhodes v. Mejer, 334 F.2d 709 (Sth Cir.), cerl. denied 379 U.S. 915 (1964); Agnew v. Moody, 330 F.2d $86 S$ (9th Cir.), cert. denied 379 US. 867 (1964); Phillips v. Nash, 311 F2d 513 (7th Cir. 1962), cert. denicd 374 US. 809 (1963); Saier v. State Bar of Michigan, 293 F.2d 756 (6th Cir.), cert. denied 363 U.S. 947 (1961); Smith v. Dougherty, 286 F.2d 777 (7th Cir.), cert. denied 368 U.S. 903 (1961); Larsen v. Gibson, 267 F.2d 386 (9th Cir.), cert. denied 361 U.S. 848 (1959); Cuilisa v. City of MIansfield, 250 F.2d 700 (6th Cir. 1957), cert. denied 356 U.S. 937; Kenncy v. Fox, 232 F.2d 288 (6th Gir.), cert. denied sub nom. Kenney v. Killian, 352 US. 855 (1950); Eaton v. Bibb, 217 F.2d 446 (7th Cir. 1954), cert. denied 350 U.S. 915 (1955); Francis v. Crafts, 203 F.2d 809 (Ist Cir.), cert. denied 346 U.S. 835 (1953).

6. The Mississippi statute under which the clergymen vere arrested was declared unconstitutional in Thomas v. Mississippi, 380 US. 564 (1965). Thomas was decided after the events complained of in Pierson.

7. 80 U.S. (13 Wall.) 335 (1872). The date of decision is sometimes given as 1871, apparently because the decision was during the December, 1871 , term of the Supreme Court. It is clear, however, that the decision was handed down nearly a year after the passage of the Civil Rights Act of 1871. This means that the 1871 Congress could not have incorporated Bradley-the first Supreme Court case to find absolute judicial immunityinto the Act. Nor can the 1871 Congress be faulted for not specifically overruling a doetrine which had not yet been accepted by the Supreme Court.

8. 341 U.S. 367 (1951).

9. 386 U.S. at 554-55.

10. Floyd \& Barker, 12 Co. Rep. 23 (1608).

11. It has been suggested that "judges, as the ones administering tort liability, base 
that "an action will not lie against a judge for a wrongful commitment, or for an erroneous judgment, or for any other act made or done by him in his judicial capacity."12

Since judicial immunity is purely a common-law rule, it could presumably be overruled with impunity by legislation such as Section 1983. ${ }^{13}$ The first few courts that explored the question of whether judicial immunity applied to actions under Section 1983 concluded that it did not. ${ }^{14}$ Once the Supreme Court decided Tenney, however, judicial immunity was read into the statute by analogy to the rule re* garding state legislators. ${ }^{15}$ Though superficially appealing, this analogy ignores at least three significant factors: (1) the wording of the statute -judges act "under color" of law, but legislators usually "enact" law; 10 (2) the obvious parallel between state and federal legislators, the latter constitutionally immune from suit for acts done in their legislative capacity; ${ }^{17}$ and (3) the disparate attitudes of the Radical Republican congresses toward legislative and judicial power. ${ }^{18}$

at least had no reason for being unfriendly toward their own immunity." E. Jennitigs, Tort Liability of Administrative Officers, 21 MinN. L. REv. 263, 272 (1937).

12. Grove v. Van Duyn, 44 N.J.L. 654, 656 (E. \& A. 1882). Formerly, the rulc did not apply to judges of courts of limited jurisdiction acting outside thcir jurisdiction, even innocently, because such a rule encouraged judges to keep within their jurisdiction. T. COOLEY, LAw OF TORTS 491 (2d ed. 1888). All courts are now upon the same footing. however, Case Note, 13 ARK. L. REv. 145, 146 (1959), and judges are protected if the matter is colorably within their jurisdiction. 44 N.J.L. at 660 .

13. The few arguments that judicial immunity is a constitutional requirement have been singularly unconvincing. Bauers v. Heisel, 361 F.2d 581, 588-89 (3rd Cir. 1966) (guarantee of a republican form of government); Ex Parte Virginia, 100 U.S. 339,862 (1879) (dissenting opinion) (invading reserved powers of states). The Baucrs court adle mitted that the "guarantee of a republican form of government" clause was nonjusticia ble, but contended that it could be used as an aid in statutory interpretation. 361 ri.2d at 589.

14. Picking v. Pennsylvania R. Co., 151 F.2d 240 (3rd Cir. 1945) was the first case to deal squarely with the issue, deciding that Congress did not intend to allow judicial immunity as a defense to a $\$ 1983$ action. Picking was followed in McShane v. Moldovan, 172 F.2d 1016 (6th Cir. 1949) and Burt v. Gity of New York, 156 F.2d 791 (2d Cir. 1916).

15. See, e.g., Kenney v. Fox, 232 F.2d 288 (6th Cir. 1956), cert. denied sub nom. Kenncy v. Killian, 352 U.S. 855 (1956).

16. Senator Trumbull made this distinction in the debate on an analogous provision, § 2, 14 Stat. 27 (1866), in the Civil Rights Act of 1866. Conc. Grobe, 39th Cong., 1st Sess. 1758 (1866). Of course, legislators do much more than "enact" law, and an argument can be made that when legislators go far beyond the legislative power (as was alleged in Tenney) the immunity ought not to apply. The problem with this is that, accepting the proposition that there ought to be some area of complete legislative immunity, any distinction between what is immune and what is not must rest upon how far outside the scope of the legislative power the particular legislator acts, not how maliciously he acted, or how much damage he caused. This means that individuals, acting within an ill-defined power may be absolutely immune, no matter how maliciously thcy act, but if they unknowingly step outside that power for a moment, they will find themselves fully liable. To put it simply, resting a question of liability upon whether a particular action is or is not "legislative" seems ill-advised.

17. U.S. CoNst. Art. I, $\$ 6$. The Supreme Court, in Tenney v. Brandhove, 341 U.S. 367, 376 (1951), expressed serious constitutional doubts about holding state legislators liable for actions within the scope of their duties, although no constitutional provision was cited to support the court's misgivings.

18. The Court pointed out in Tenney that the Radical Congress was a "staunch ad. 
The wording of the statute would appear to be all-inclusive: Section 1983 in its present form applies to "every person," and the Act as passed applied to "any person." 10 The unrevised text of the Act also declared that any person was liable "any . . . law, statute, ordinance, regulation, custom or usage to the contrary notwithstanding." ${ }^{\prime \prime}$ It is certainly hard to imagine a broader definition. ${ }^{21}$

The usual argument against this simple interpretation of the statutory language is that since judicial immunity had been entrenched in the common law for several centuries ${ }^{22}$ Congress would not have overruled this venerable doctrine without saying so with specificity. It is a standard maxim of interpretation that a statute should not be construed in derogation of the common law without strong evidence that the legislature intended that effect. ${ }^{23}$ However, the major premise of the syllogism is defective: judicial immunity was not a universal doctrine.

The immunity began, of course, in England, and English decisions have consistently held judges absolutely immune from liability for their judicial acts. ${ }^{24}$ Yet even this broad immunity applied only to judges of superior courts; justices of the peace, acting within their authority, were liable to civil suit if they acted maliciously. ${ }^{25}$

The English rule did not win immediate and widespread acceptance in the United States. Since Bradley was not decided until April 1872 (a year after passage of the Civil Rights Act), a legislative inquiry into the subject would have disclosed Randall $v$. Brigham ${ }^{20}$ as the lead-

vocate of legislative freedom." 341 U.S. at 376. The Radical Congress did not think so highly of judicial autonomy, as evidenced by repeal of the right to appeal habeas corpus cases to the Supreme Court Ex Parte MicCardle, 7 Wall. 506 (1869). See pp. 327-28 infra.

19. The change in wording was made, apparenty for acsthetic purposes, by the reviser who prepared the Revised Statutes of 1878 . Of course, he had no power to make substantive changes.

20. 17 Stat. 13 (1871).

21. Picking v. Pennsylvania R. Co., 151 F.2d 240 (3rd Cir. 1945).

22. "It is to be found in the earliest judicial records, and it has been steadily maintained by an undisturbed current of decisions in the English courts . . ." Yates $v$. Lansing, 5 Johns. 282, 291 (N.Y., Sup. Ct. of Judicature 1810).

23. See, e.g., American Dist. Tel. Co. Y. Kittleson, 179 F.2d 946 (8th Cir. 1950); Scharfeld v. Richardson, 133 F.2d 340 (D.C. Cir. 1942).

24. See, e.g., Everett v. Griffiths, 2 A.C. 631 H.L. (1921); Dawkins v. Lord Paulet, L.R. 5 Q.B. 94 (1869); Scott v. Stansfield, L.R. 3 Ex. 220 (186S); Tasfe v. Dornes (I8I3), reported in Calder v. Halket, 13 Eng. Rep. 12 at 36n. (P.C. 1839); Flojd \& Barker, 77 Eng. Rep. 1305 (Star Chamber 1608).

25. The Justices Protection Act, 11 \& 12 Vict. c. 44 (1848) so stated. A previous act, 43 Geo. 3 c. 141 (1803) had limited damages to twopence unless malice and lack of reasonable and probable cause was proved. See Pease v. Chaytor, 3 B. \& S. 620, G14 (K.B. 1863); Burley v. Bethune, 5 Taunt. 580 (C.P. 1814). A similar rule limiting the immunity of inferior judges was formerly in effect in the United States. See note 12 supro. Under the English rule, the defendant magistrates in Pierson, or in Tate v. Arnold, 223 F.2d 782 (8th Cir. 1955), for example, would not have been absolutcly immune.

26. 74 U.S. (7 Wall.) 523 (1868). 
ing Supreme Gourt case. There, the Court held that judges of courts of general jurisdiction were not civilly liable for their judicial acts, "unless, perhaps where the acts, in excess of jurisdiction, are done maliciously or corruptly." ${ }^{27}$ The phrase "in excess of jurisdiction" apparently does not mean that the judge did not have power over the person or the subject matter, although what the phrase does mean is unclear. Justice Field in Bradley overruled his dictum in Randall, and explained the difference between acts "totally without jurisdiction"for which, even under Bradley, judicial officers could be held liable -and acts "in excess of jurisdiction" for which, Bradley held, they could not be held liable. Field's example of acting totally without jurisdiction was a probate judge trying a criminal case, while an act "in excess of jurisdiction" would be a judge improperly holding a particular act to be a crime or sentencing a defendant to more than the statutory maximum. ${ }^{28}$ Thus, a diligent congressman, looking to the federal rule in 1871, would have had no reason not to surmise that an incorrect ruling of law, maliciously made, which deprived an in* dividual of his constitutional rights, would probably subject the offending judge to liability. This would hardly indicate that Congress, intending to subject judges to liability, would feel compelled to state explicitly that judicial officers would come under the Act.

Nor would Congress have found a clearly defined doctrine of absolute immunity in the prevailing law in the states. By 1871, thirteen states had adopted the absolute immunity rule; ${ }^{20}$ six states had ruled

27. Id. at 536 .

28. 80 U.S. (13 Wall.) at 352. A definition of "in excess of jurisdiction," though in a different context, was given in McClatchy v. Superior Court, 119 Cal. 418, 51 Pac. 696 (I897):

Any departure from those recognized and established requirements of law, howa ever close the apparent adherence to mere form in method of procedure, which has

the effect to deprive one of a constitutional right, is as much an excess of jurisdic.

tion as where there exists an inceptive lack of power. Id. at 418 .

See Broom v. Douglass, 175 Ala. 268, 279, 57, S. 860 (1912); Comment, Federal Comity, Official Immunity and the Dilemma of Section 1983, 1967 Duke L.J. 741, 752 n.54.

29. Alabama: Hamilton v. Williams, 26 Ala. 527 (1855). Arkansas: Borden v. State to use of Robinson, 11 Ark. 519 (1851). California: Den v. Fernald, 1 Cal. Unrep. 70 (Sup. Ct. 1859); Downer v. Lent, 6 Cal. 94 (1856). Connecticut: Holcomb v. Cornish, 8 Conn. 374 (1831); Phelps v. Sill, I Day's Cases 315 (1804); but see Ambler v. Church, 1 Root 211 (1790). Delaware: Bailey v. Wiggins, 1 Houst. 299 (1856). Massachusetts: Pratt v. Gurdner, 56 Mass. 63 (1848). Missouri: Pike v. Megoun, 44 Mo. 491 (1869); Lenox v. Grant, 8 Mo. 254 (1843); but see Reed v. Conway, 20 Mo. 22 (1854). New Hampshire: Burnlam v. Stevens, 33 N.H. 247 (1856). New Jersey: Taylor v. Doremus, 16 N.J.L. 173 (1838); Little v. Moore, 4 N.J.L. 74 (1818). New York: Yates v. Lansing, 5 Johns. 282 (Sup. Ct. of Judicature 1810); but see Yates v. Lansing, 9 Johns. 395 (Senate 1812). North Carolina: Furr v. Moss, 52 N.C. 525 (1860); Cunningham v. Dilliard, 20 N.C. 350 (1839); lut set Hardison v. Jordan, Cam. \& Nor. 454 (1803). Virginia: Austin v. Richardson, 42 Va. 810 (1844). The Virginia legislature had enacted a statute making judges liable personally in the appointment of guardians if they did so erroneously in a willful or culpably negli* 
that judges were liable if they acted maliciously; ${ }^{30}$ in nine states, courts had faced the issue but had not ruled clearly one way or the other; 31 and nine states had apparently not yet faced the issue. ${ }^{32}$ Here again, there was not the solid unanimity which would compel a legislature specifically to reject an acknowledged immunity.

The legislative debates on the proposed Act provide a third index of congressional intent. Though the first section of the 1871 Act-now Section 1983-did not receive a great deal of attention, all the available evidence points to the conclusion that Congress intended to cover judges. The bill was introduced by Rep. Shellabarger, who stated that the model for Section 1983 was the second section of the Civil Rights Act of 1866,33 and "that section provides a criminal proceeding in identically the same case as this one provides a civil remedy for." 34 The Civil Rights Act of 1866 had been vetoed by President Johnson, partially because it subjected state judges to criminal liability. ${ }^{35}$ In the successful fight to overcome the veto, the chairman of the Senate Judiciary Committee attacked the entire concept of judicial immunity and stated that judges would indeed be liable under the bill. ${ }^{30}$

gent manner. Id. at 323. Wisconsin: Druecker v. Salomon, 21 Wis. 621 (I867); Keeler v. Woodard, 4 Chand. 34 (1851).

30. Indiana: State ex rel. Conley v. Flinn, 3 Blackf. 72 (1832); State ex rel. Robinson v. Littlefield, 4 Blackf. 129 (1835). Iowa: Wasson v. Mitchell, 18 Iowa 153 (1864). Kentucky: Revill v. Pettit, $60 \mathrm{Ky}$. 314 (1860); Gregory v. Brown, $4 \mathrm{Bibb} 28$ (1815). Mranjland: Friend v. Hamill, 34 MId. 479 (1862). South Carolina: State ex rel. Tavel v. Jercey, 4 Strobh. 304 (1850); Macon v. Cook, 2 N. S MIC. 168 (1819). Tennescec: Cope v. Ramsey, 49 Tenn. 197 (1870); Hoggatt v. Bigley, 25 Tenn. 236 (1845).

31. Georgia: Warthen v. May, I Ga. 602 (1846); Upshaw v. Oliver, Dudley's Rep. 241 (Elbert Super. Ct. 1832). The issue was further clouded by Gault v. Wallis, $53 \mathrm{Ga} .675$ (1875). Illinois: Lancaster v. Lane, 19 Ill. 242 (1857); Flack v. Alkeny, 1 Ill. 187 (1820). Kansas: Clark v. Spicer, 6 Kan. 440 (1870). Louisiana: Lilienthal v. Campbell, 22 La. Ann. 600 (1870). Maine: Downing v. Herrick, 47 Me. 462 (1859). Mfichigan: Gordon v. Farrar, 2 Doug. 411 (1847). Nebraska: Morgan v. Larsh, 1 Neb. 361 (1871). Pennsylvania: Kennedy v. Barnett, $64 \mathrm{~Pa}$. 141 (1870). Dermont: Davis v. Strong, 31 vt. 332 (I85S); Fuller v. Gould, $20 \mathrm{Vt} .643$ (1848).

32. Florida, Minnesota, Mississippi, Nevada, Ohio, Oregon, Rhode Island, Tesas, West Virginia.

33. 14 Stat. 27 (1866). The provision, amended several times, is now 18 US.C. $\$ 242$.

34. Cong. Globe, 42nd Cong., 1st Sess. GB (App.) (1871).

35. Cong. Grobe, 39th Cong., Ist Sess. 1680 (1860) (President's Message to Congress).

36. "[The doctrine of immunity] places officials above the law. It is the very doctrine out of which the rebellion was hatched." CoNG. GLoBE, 39th Cong., 1st Sess. 1758 (1866) (remarks of Senator Trumbull). There are similar statements by other members of Congress:

Any judge . . . who is called upon to decide whether the State law is in force because this law is unconstitutional, shall it to be in force notwithstanding this law, is to be punished. Id. I778 (remarks of Senator Johnson).

Representative Iawrence also stated that judges would be liable under the 1866 Act: $I$ answer it is better to invade the judicial power of the States than permit it to invade, strike down, and destroy the civil rights of citizens. A judicial power perverted to such uses should be speedily invaded .... And if an officer shall intentionally deprive a citizen of a right, knowing him to be entitled to it, then he is guilty of a willful wrong which deserres punishment. Id. 1837. 
There is no indication that Congress had acquired any greater respect for judicial prerogative by 1871 . The Southern courts were "under the control of those who are wholly inimical to the impartial administration of law and equity." ${ }^{37}$ One representative saw courts in the South as tools of rebel partisans:

$[\mathrm{T}]$ he decisions of the county judges, who are made little kings, with almost despotic powers to carry out the demands of the legislature which elected them-powers which, almost without exception, have been exercised against Republicans without regard to law or justice, make up a catalogue of wrongs, outrageous violations, and evasions of the spirit of the new constitution, unscrupulous malignity and partisan hate never paralleled in the history of parties in this country or any other. ${ }^{38}$

On three occasions during the debates, legislators explicitly stated that judges would be liable under the Act. ${ }^{30}$ No one denied the statements. ${ }^{40}$

In sum, the question of congressional intent seems relatively clear: there was no universal acceptance of the broad English immunity rule in 1871, and the only legislative history available supports the proposition that Congress intended Section 1983 to cover judges. Still,

37. Cong. Glone, 42nd Cong., 1st Sess. 394 (1871) (remarks of Rep. Rainey).

38. Id. 186 (App.) (remarks of Rep. Platt). For similar statements, see id. 391 (remarke of Rep. Rainey); id. 429 (remarks of Representative Beatty); id. 153 (App.) (remarks of Representative Garfield); id. 277 (App.) (remarks of Rep. Porter); id. (remarks of Rep. Lansing); id. 315 (remarks of Rep. Burchard); id. 505 (remarks of Senator Pratt); id. 179 (App.) (remarks of Rep. Voorhees); id. 654 (remarks of Senator Oshorne).

39. Senator Thurman stated:

What is to be the case of a judge? .. Is that State judge to be taken from his bench? Is he to be liable in an action?... It is the language of the bill; for therc is no limitation whatsoever on the terms that are employed, and they are as com. prehensive as can be used. Id. 217 (App.).

The remarks in the House of Representatives were even more emphatic. Representative Lewis complained that

[b]y the first section, in certain cases, the judge of a State court, though acting under oath of office, is made liable to a suit in the Federal Court and subject to damages for his decision against a suitor, however honest and conscientious that decision may be .... Id. 385 .

And Representative Arthur declared:

Hitherto, in all the history of this country and of England, no judge or court has been held liable, civilly or criminally, for judicial acts ... . Willtulness and corrup. tion in error alone created a liability .... Under the provisions of this scction every judge in the State court ... will enter upon and pursue the call of official duty with the sword of Damocles suspended over him .... Id. 365-66.

40. The Third Circuit in Bauers v. Heisel, 361 F.2d 581 (3rd Cir. 1966) dismissed two of the statements in note 39 , supra as "little more than opposition remarks," adding that opponents' statements only have relevance where the proponents made no response to them, 36I F.2d at 587-88, n.8. The court concluded that responses could not be cxpected because of the times when they were made. Id. On at least one of these two occistons, Representative Shellabarger, the floor manager of the bill, was present, and he was not loath to interrupt speakers who were misconstruing the bill. Cong. Grone, 42nd Cong., lst Sess. 382 (1871). Further, it would seem odd that such a misapprehension would not be corrected when a single sentence could have clarified the matter. 
the legislative history does not preclude entirely the Court's construction of the statute if the policy reasons for judicial immunity are sufficiently persuasive.

In turning to those policy considerations, one finds in Pierson only the following passage to justify judicial immunity:

It is a judge's duty to decide all cases within his jurisdiction that are brought before him, including controversial cases that arouse the most intense feelings in the litigants. His errors may be corrected on appeal, but he should not have to fear that unsatisfied litigants may hound him with litigation charging malice or corruption. Imposing such a burden on judges would contribute not to principled and fearless decision-making but to intimidation."1

The Court did not indicate which of these reasons it was relying on, nor did it offer all the arguments for the immunity that the literature reveals. Three separable reasons, however, may be discerned from the opinion.

The first of these is that a judge's decision is appealable, and, therefore, the party need not sue the judicial officer to vindicate his rights.42 But decisions of judicial officers are not necessarily appealable, ${ }^{23}$ and appeal is not always a satisfactory remedy. The Court itself has recognized that a citizen's rights may be seriously violated even if he is not ultimately convicted.44 An individual or group facing litigation which is intended only to harass ${ }^{45}$ will take little comfort indeed from

41. Pierson v. Ray, 386 U.S. $547,554$.

42. See Jennings, note 11 supra at 272.

43. The appealability argument applies to most judges, but not to judicial officers generally. For example, there are no procedures for appealing from the decisions of a prosecuting attomey or a prison warden. Thus, no rationale for a broad judicial immunity may be based upon vindication upon appeal.

44. Dombrowski v. Pfister, 380 U.S. 479 (1965). A plaintiff need not pursue his state remedies before instituting a $\$ 1983$ action, Monroe v. Pape, 365 U.S. 167 (1961), which would seem to recognize that appealability simply is not sufficient protection.

45. One of the injustices referred to in the Civil Rights Aet debates was the use of harassing litigation:

That plan is, by harassing litigations, unjust persecutions upon trivial and false charges, to accomplish one of two things: first, to silence the tongue, overawe the courage and utterly subdue all political opponents, or, failing in that, to make it impossible for them longer to remain in the State ....

CONG. GLOBE, 42nd Cong., 1st Sess. 185 (App.) (remarks of Rep. Platt). By a serics of harassing measures, judges and public prosecutors (also protected by judicial immunity) could cause their opponents great inconvenience and discomfort, as well as heavy legal expenses. The fact that such litigation is virtually certain to lose is irrelevant to one whose main intent is to harass, not to convict, and the fact that his cause will ultimately be vindicated is small comfort to a defendant who realizes that his opponent does not expect to win. Heavy legal expenses could conceivably drive some organizations and prople out of quite legitimate if disfarored areas of activity, such as civil rights activities, and it is possible that a criminal defendant, convicted by a malicious judge, would be unable to raise an appeal bond. In some cases, injunctive relief from harassment may be available, but it has seldom been used. Note, The Federal Injunction as a Remed' for Unconstitutional Police Gonduct, 78 YaLE L.J. 143 (1968). 
his "right" to appeal. Whether or not the appeal vindicates the abused party, the inconvenience and expense of litigation remains. Moreover, if the judicial officer also serves as the "finder of fact," he may effectively preclude successful appeal.

Another rationale offered by the Pierson court is that judicial officers would be hounded by dissatisfied litigants if they were civilly liable. Justice Field in Bradley pointed out that "[f]ew persons sufficiently irritated to institute an action against a judge for his judicial acts would hesitate to ascribe any character to the acts which would be essential to the maintenance of the action." ${ }^{40}$ This plethora of lawsuits, the argument runs, would cause a great inconvenience to judicial offcers, a waste of their time ${ }^{47}$ and would be a strong deterrent to the acceptance of judicial posts by prudent men. ${ }^{48}$ This contention must derive its merit from a belief that a judicial officer will have a great deal of difficulty warding off suits which have no factual basis.

When courts first formulated the doctrine of judicial immunity, a plaintiff who pleaded properly could force a judicial officer to go to trial. This, of course, is no longer true in the federal courts: Rule 56 of the Federal Rules of Civil Procedure allows courts to dispose of the case on summary judgment if there is no genuine issue of fact. ${ }^{40}$

46. Bradley v. Fisher, 80 U.S. (13 Wall.) 335,348 (1872).

47. T. COOLEY, LAW OF TORTS 475 (2d ed. 1888).

48. U.S. v. Chaplin, 54 F. Supp. 926 (S.D. Cal., 1944); Taylor v. Doremus, 16 N.J.I. 473, 476 (Sup. Ct. 1838); Phelps v. Sill, 1 Day's Cases 315, 329 (Conn. 1804). A similar argument was made for corporate directors charged with insider trading, Goodwin $v_{\text {, }}$ Agassiz, 283 Mass. $358,362-63,186$ N.E. 659,661 (1933), but it was not convincing to
Congress, which, within a year, passed the Securities Act of 1933 , 15 U.S.C.A. $\$ \$ 77 a-77 a a$, and the Securities Exchange Act of 1934, 15 U.S.C.A. $\$ \$ 78 \mathrm{a}-78 \mathrm{jj}$.

49. 6 MOORE's FEDERAL Practice If 56.04 (2d Ed. 1965). Summary judgment has bech said to be generally inappropriate when intent is relevant, or when relevant information is peculiarly within the knowledge of the movant. Poller v. CBS, 368 U.S. 164 (1962); Others have contended that when there is an issue of credibility, the respondent should not be denied the right of cross-examination. Arnstein v. Porter, 154 F.2d 461 (2d Cir. 1946). However, summary judgment has been granted in false imprisonment litigution (which is what many $\$ 1983$ actions against judicial officers might be). Orvis v. Bricktnan, 196 F.2d 762 (D.C. Cir. 1952); Lindsey v. Leavy, 149 F.2d 899 (9th Cir. 1945). There is no generally applicable rule for refusing summary judgment when intent and credibllity are relevant:

It is submitted that the correct principle is that a court should be cautious in grant.

ing a motion for summary judgment where state of mind is involved, or where the

facts are peculiarly within the knowledge of the moving party and should be sure

that the party opposing the motion has had a fair opportunity to use the discovery

process to probe his opponent's mental state and to examine the facts his opponent

has at hand. But if, after such an opportunity, the opposing party cannot polnt to anything tangible which will create a genuine issuc of material fact, the motion should be granted.

3 Barron \& Holtzoff, Federal practice and Procedure 1232.2.

Two recent cases are particularly relevant. In Washington Post Co. v. Keogh, $865 \mathrm{Fad}$ 965 (D.C. Cir. 1966), the court gave summary judgment to a defendant charged with "actual malice." See note 3 supra. In Bradford v. School Dist. No. 20, 364 F.2d 185 (4th Cir. 1966) summary judgment was granted to a defendant school board in a 1983 action in which the board was charged with intentional discrimination. 
Moreover, the government to which the officer is responsible could be expected to defend a suit against him, ${ }^{t 0}$ thus eliminating any great expense to him. It may also be that the type of person who would bring a suit with no basis in fact would be just as likely to do so with a rule of absolute immunity, since the plaintiff could state a good cause of action by alleging that the judicial officer was acting entirely without jurisdiction. ${ }^{51}$ In either event, the judicial officer would be put to some inconvenience but a court could dispose of frivolous claims with dispatch. Most importantly, allowing considerations of public officers' convenience to dictate immunity runs counter to fundamental public policy:

The courts should be wary of any argument based on the fear that subjecting government officers to the nuisance of litigation and the uncertainties of its outcome may put an undue burden on the conduct of public business. Such a burden is hardly one peculiar to public officers ... [ [b]ut the way to minimizing the burdens of litigation does not generally lie through the abolition of a right of redress for an admitted wrong.5?

The Pierson court also argued the much supported vievis that judicial liability would detract from "principled and fearless decisionmaking" and destroy the independence of judicial officers by intimidation, but any argument that the pressure of liability would encournge unprincipled-read "wrong," apparently-decisions must presume a general weakness in judicial fibre. It does not logically follow that principle automatically flees from a fear of law-suits. Subjecting of-

50. See, e.g., CAL. Govr. CoDE § 825. As a general rule, state governments will defend against such actions.

51. In Spires v. Bottorf, 317 F2d 273 (7th Cir. 1963), cert. denied 379 U.S. 939 (1961) the plaintiff was able to avoid judicial immunity, apparently on this ground. The defendant judge had disqualified himself from hearing the plaintiff's case, but had allegedly interfered constantly in further litigation. Determination of total absence of jurisdiction might be an easier case for summary judgment because the main issue would probably be the extent of the defendant officer's jurisdiction, a question of law. However, a plaintiff in a $\$ 1983$ action might allege spurious jurisdictional facts in his complaint against the officer, which, if true, would have meant that the defendant was acting wholly without jurisdiction. In that case, both parties would be in the same situation they would be in if the plaintiff baselessly alleged malice.

52. Barr v. Matteo, 360 U.S. 564, 588.89 (1959) (Brennan, J., dissenting). Justice Brennan roted with the majority in Pierson, apparently not on Uis ground. Barr was a defamation case in which the defendant pleaded privilege. The defence of official privilege in defamation actions is generally considered to stand on the same theoretical footing as the defense of immunity to tort actions generally. W. Prosser, THE LAW of Torms 607 (2d ed. 1955).

53. Bradley v. Fisher, 80 U.S. (13 Wall.) 335, 347 (1872); Stewart v. Coolcy, 23 MIinn. 347,350 (1877); Grove v. Van Duyn, 44 N.J.L. 654,656 (E. \&. A. 18sM; Litte v. Mloore, 4 N.J.L. 74 (E. \& A. 1818); Yates v. Lansing, 5 Johns. 282, 298 (N.Y. Sup. CL. of Judicature 1810); Taafe v. Downs (1813) reported in Calder v. Halket, 13 Eng. Rep. 12, $86 n$. (P.C. 1839).

54. "I cannot bring myself to believe that officers in command vould hesitate to give 
ficers to Section 1983 liability is, of course, intended to be a control on conduct, but the pressure should usually favor making as fair and honest a decision as possible after reasonably diligent research.

Nevertheless, a judge may regularly find himself in situations where only one of the parties before him is a potential plaintiff for a Section 1983 civil suit. For example, in a criminal prosecution such as Pierson, the state could not reasonably attack a judge's ruling on the ground that it abridged the state's constitutional rights. Thus the judge might be influenced by the possibility of civil liability to decide any given case in favor of the party in a position to file an action under Section 1983. Part of the answer to this admittedly meritorious point is that constitutional rights are more important than other considerations. More to the point, however, the fact that pressure on the judicial officer encourages him to decide for the party with the potential constitutional claim does not establish the necessity for complete immunity. Rather, it supports only the requirement that the plaintiff show something more than an honest judicial mistake, or perhaps more than mere judicial negligence. If the terms "fearless decision-making" and "judicial independence" mean that a juclicial officer should be free to reach any decision he wishes, for any motive he wishes then Section 1983 liability will indeed undermine such "in" dependence," and rightly so.

Quite apart from the Court's rationale in Pierson, courts and commentators have presented other arguments for judicial immunity. The Bradley Court opined that judges owe duty only to the government, not to individual citizens. Concomitantly, a judge may be impeached, but he cannot be held liable to a citizen for damages. By this reasoning, absolute immunity should apply to all governmental officers, but even Pierson acknowledged that it does not. ${ }^{55}$ Also, there is no inconsistency between the judicial officer's duty to the government and a duty to citizens not to deprive them of their constitutional rights. A citizen can legitimately expect an officer, commissioned by the law, to act only with due respect of individual rights; if he deliberately does not respect those rights and causes injury, he is not acting within the protection of his commission. ${ }^{56}$ Finally, a remedy as seldom used ${ }^{67}$

orders which a sense of duty required ... from any idle apprehension of being harassed by vexatious actions." Dawkins v. Lord Paulet, L.R. 5 Q.B. 94, 108 (1869) (Cockburn, G.J., dissenting).

55. In Pierson, the court held that police officers are liable if they act maliciously and without probable cause. 386 U.S. at 555 (1967).

56. Raynsford v. Phelps, 43 Mich. 342, 346 (1880).

57. A survey of forty states found that a total of only fifty-two impcachment pro- 
as impeachment is even more seldom adequate. Legislators may well be unwilling to avenge a judicial harm to a particular individual or class, and even where invoked, impeachment of the offending officer affords the injured party no relief other than revenge. In short, the impeachment argument assumes something to be true which, by the very passage of the $1871 \mathrm{Act}$, Congress determined to be untrue: that state governments are always willing and able to enforce individual rights.

Others have contended that respect for the judiciary would diminish and judicial dignity would suffer if judges were to be subject to liability in civil actions based on their judicial acts.58 Respect for the judiciary is desirable, but popular respect is hardly engendered by the knowledge that, by reason of a judge-made rule, a judicial officer may maliciously abuse his powers and leave the citizen without remedy. Respect for the judiciary is only one aspect of respect for the law, and if the two conflict, the latter should prevail. One might argue that there are some types of judicial dignity it would be better to do without. 59

The strongest reason for judicial immunity may lie in the uncertainties of the fact-finding process: suits might force a defendant judicial officer to attempt an explanation of his mental processes in a particular case. $^{60} \mathrm{It}$ is somewhat anomalous to place an official

in a position the very significance of which is to require his opinion and accord it especial deference in the matter at hand, and yet at the same time to penalize him with personal consequences by reference to the opinion of another or others in regard to the same matter. ${ }^{61}$

Certainly a judge's position in such a case would not be unique. Police

ceedings had ever been instituted, resulting in nineteen removals. Brand, The Discipline of Judges, 46 ABAJ 1315 (1960). See F. Miller, Discipline of Judges, 50 Arici. L. REv. 737 (1952).

58. See, e.g., Hamilton v. Williams, 26 Ala. 527, 533 (I855); Grove v. Van Duyn, 44 N.J.L. 654, 656 (E. \& A. 1882); Floyd \& Barker, 12 Co. Rep. 23 (Star Chamber 160S); T. COOLEY, LAw OF TORTS 476 (2d ed. 1888).

59. See J. Frank, The Cult of the Robe, Saturday Rev. of Imterature 12 (Oct. 13, 1945). The judicial dignity argument has, on occasion, been turned around with the statement that making a plaintiff remediless against a malicious or corrupt judge would undermine respect for the judiciary:

This conduct... would, if tolerated by law, bring the judicial department into merited odium and contempt.

State ex rel. Conley v. Flinn, 3 Blackf. (Ind.) 72,74 (1837).

60. "The result is made to depend not upon his own original conviction ... but upon the conclusions of other minds, under the influence of different considerations." Pratt v. Gardner, 56 Mass. (2 Cush.) 63, 70 (1848). See Pierson v. Ray, 386 US. 547, 566 (1967) (Mr. Justice Douglas dissenting).

61. Jennings, note 11 supra at 273 . 
officers, who must often exercise discretion in situations often far more pressing than those judicial officers face, have only a qualified immunity. ${ }^{62}$ Indeed, the argument is really addressed to difficulties of the factfinding process, not to unique characteristics of judges: nearly any defendant may find himself in a similar position, but no other defendant can claim complete immunity. If the previous arguments for judicial immunity do not establish the soundness of the doctrine, this argument makes little sense. ${ }^{.3}$

The foregoing rationales offered by the apologists for judicial immunity simply cannot support the doctrine. Replacing the immunity with a system of some liability for judicial officers raises the troublesome question of defining the proper standard of liability. The present standards for those officials who are subject to suit under Section 1983 are not entirely clear. Police officers, the most frequent defendants in Section 1983 suits, are allowed the affirmative defense of good faith and probable cause. ${ }^{64}$ The chief difference between the affirmative defense given to police officers and a malice standard is simply one of burden of proof: a police officer, in order to escape liability, must plead and prove that he acted in good faith, while a plaintiff would have the burden of proving malice if actual malice were to be the standard of liability for judicial officers.

The alternative to this subjective test is a standard of liability built upon negligence. Though the arguments for immunity are hardly persuasive, they do contain some valid points which support the view that a negligence standard for judicial liability is unsatisfactory.

62. See note 55 supra. In regard to police discretion, see President's Commission on LAW ENFORCEMENT AND ADMINISTRATION OF JUSTIGE, TASK FORCE REPORT: TIIE POLICL 14 (1967); H. Goldstein, Police Discretion: The Ideal Versus the Real, 23 Puw. ADMN. REv. 140 (1967); Note, Police Discretion and the Judgment that a Crime has becn Committed-Rape in Philadelphia, 117 U. PA. L. REv. 277 (1968).

Some courts have held police officer defendants to a negligence standard in 1988 actions, at least in certain circumstances. Whirl v. Kern, 407 F.2d 781 (5th Gir. 1969) Joseph v. Rowlen, 402 F.2d 367 (7th Cir. 1968); Anderson v. Haas, 311 F.2d 497 (3rd Gir. 1965). Whirl harkened back to the common law and said that $\S 1988$ cases that cound in the common law action of false imprisonment required only a negligence standard. Joseph said that good faith was not available as a defense if the officer lacked both prob. able cause and a warrant.

63. There is another argument sometimes made for judicial immunity, but full discussion of it is not required due to its essentially frivolous nature. It is contended that judicial liability could make for unending litigation, with a dissatisfied litigant sulng Judge $A$ at a trial presided over by Judge $B$, who is sued in a trial presided over by Judge $C$, and so on. COOLEY on TORTS 476-477 (2d ed. 1888). Obviously, summary judy. ment is appropriate when a judge is faced with a compulsive litigant, and little judicial time would be wasted.

64. The Pierson Court appeared to rely upon the general common law of torts in deciding that this affirmative defense existed. 386 U.S. at 557. If the common law is to be the basis for determining what standards of liability apply, then the standard of liability differs, depending upon what type of officer is involved. 
The inherent problems of the fact-finding process would be particularly acute if negligence were the standard of liability. Because a defendant judicial officer is a "professional," his conduct would be measured against the standards of competence in his profession. Experts would confront the finder of fact with a confusing array of testimony almost certain to bog down a trial, particularly if the case is tried to a jury. The action would be one essentially for judicial malpractice, with at least the same complexity and fogginess that characterize analogous trials in the medical profession. ${ }^{05}$ The real possibilities for "hounding" in this situation are obvious.

Nor could the hounds be driven off easily with a motion for summary judgment. Negligence cases are generally considered inappropriate for summary judgment, ${ }^{66}$ and, in all probability, the affidavit of one "expert" witness would be sufficient to raise an issue of fact for trial.

The major function of a negligence standard would be to demand judicial competence at the peril of civil liability. ${ }^{07}$ Not only are there seemingly more effective ways of ensuring competence, but liability for negligence might lend credibility to the assertion that inroads upon judicial immunity would deter even competent persons from accepting judicial roles, particularly underpaid, political appointments. Moreover, and perhaps less speculatively, the recognized pressure ${ }^{c 5}$ to decide in favor of the party with a potential Section 1983 action may be a significant factor when an admittedly incompetent judicial officer is attempting to protect himself from his own incompetence. A certain number of honest errors by judges is tolerable, and a negligence standard for Section 1983 liability might create more problems than it could conceivably be intended to solve.

The serious drawbacks a negligence standard would present for the judicial process demonstrate that it is unworkable, but an "actual malice"69 standard has none of these disadvantages and comports well with the Congressional intent of Section 1983.70 The reasons for holding a judicial officer liable when he has deliberately or recklessly de-

65. For a discussion of the problems facing the finder-of-fact in medical malpractice trial, see A. Cohn, Medical Malpractice Litigation: $A$ Plague on Both Houses, 52 A.B.A. JouRNAL 32, 33 (1966); L. MYyers, "The Battle of the Experts": A New Approach to on Old Problem in Medical Testimony, 44 NEs. L. REv. 539, 555.557 (1965).

66. 6 MOORE's FEDERAX PRACTICE II 56.17, at 42 (2d ed. 1965). See Note, Use of Summaty Judgment by Types of Case, 36 MINN. L. REv. 515, 519 (1952).

67. See Pierson v. Ray, 386 U.S. 547, 566 (1967) (dissenting opinion of Justice Douglas).

68. See p. 331 supra.

69. See note 3 supra.

70. See pp. 325-28 supra. 
prived an individual of a constitutional right are obvious; they go to the heart of the concept of tort liability.

It does indeed go without saying that an official, who is in fact guilty of using his powers to vent his spleen upon others, or for any other personal motive not connected with the public good, should not escape liability for the injuries he may so cause. ${ }^{71}$

The problem is often presented as one of assumptions: postulating a malicious defendant, it seems unjust to deny recovery; postulating an "innocent" defendant, it appears wasteful to force him to face the wrath of disappointed litigants. Plaintiffs whose grievances are real ought to be compensated, and innocent judges ought to be protected from liability and harassment. An actual malice standard for judicial liability allows at least partial realization of the first goal, while fully achieving the second.

The malicious deprivation of protected rights is, as Harper and James point out, quite a different matter than understandable errors:

Where the charge is one of honest mistake, we exempt the officer because we deem that an actual holding of liability would have worse consequences than the possibility of an actual mistake (which under the circumstances we are willing to condone). But it is stretching the argument pretty far to say that the mere inquiry into malice would have worse consequences than the possibility of actual malice (which we would not, for a minute, condone). Since the danger that official power will be abused is greatest where motives are improper, the balance here may well swing the other way. ${ }^{72}$

It is not a question of demanding competence when there is some doubt that judicial officers can uniformly perform at that level, since even the most incompetent officer can be diligent and fair-mindedqualities certainly to be encouraged in public officials at every level. Moreover, the malice standard places no strain on the independence of the conscientious judge who decides close cases against the party arguing a deprivation of constitutional rights. The only pressure involved is exerted against the free rein to prejudice and abuse of judicinl power.

The inquiry into malice would entail more simplified trial issues than a negligence standard and would render "expert" testimony largely irrelevant. The questions presented would be the factual issue

71. Gregoire v. Biddle, 177 F.2d 579, 581 (2d Cir. 1949).

72. F. HARPER \& F. JAMEs, The LAw OF TORTS 1645 (1956). 
of the judicial officer's motive and whether sufficient evidence appears to substantiate that the deprivation of rights was malicious. Presumably, the judicial officer would not be likely to state or depose that he had acted with malice; but the plaintiff attempting to demonstrate reckless disregard or actual malice from the surrounding circumstances and the judicial officer's statements would bear a heavy burden of proof. ${ }^{73}$ Moreover, the summary judgment procedure is proper and likely to be determinative when pretrial discovery and affidavits disclose no evidence of abuse.

Generally, a government cannot be sued for the malicious torts of its employees; ${ }^{74}$ but if judicial officers were liable under Section 1983, their governments might freely choose, or be forced, to assume liability. This would not only provide an equitable method of compensation, but governmental assumption of liability might encourage the resuscitation of moribund removal and impeachment procedures to provide an indirect control on the conduct of malice-prone judicial officers.

But whatever the long term results of imposing liability, there is no adequate rationale-in history or policy-for altogether exempting judicial officers from liability under Section 1983. The hoary doctrine of judicial immunity, however, has had remarkable durability; it is likely that inroads upon the doctrine will be accomplished only by legislative intervention in terms more specific than even the seemingly unequivocal language of Section 1983.

73. The presence of malice would often depend upon the degree of discretion the judicial officer had. A judge who consistently decides a particular type of case in a manner which deprives individuals of their civil rights, despite repeated reversals, and, perhaps, a definitive statement on the matter by the Supreme Court, would clearly be decmed malicious. Members of a state parole board, whose only mandate may be a very unclear statement from the legislature, would be less likely to be found malicious because of the very absence of standards in the field. However, even in this latter instance, circumstances can be imagined where the member(s) of the board may quite properly be found to be acting maliciously.

74. E.g., CAL. Govt. CODE § 825.6. Cf. 38 U.S.C. $\$ 2680(\mathrm{~h})$. 